\title{
Dry bulk shipping flows to 2050: Delphi perceptions of early career specialists
}

\author{
John Dinwoodie ${ }^{\mathrm{a}, *}$, Melanie Landamore ${ }^{\mathrm{b}}$, Patrick Rigot-Muller ${ }^{\mathrm{b}}$ \\ a Plymouth Graduate School of Management, Plymouth University, Plymouth PL4 8AA, UK \\ b School of Marine Science and Technology, Newcastle University, Newcastle-upon-Tyne NE1 7RU, UK
}

\section{A R T I C L E I N F O}

\section{Article history:}

Received 4 January 2013

Received in revised form 6 March 2014

Accepted 17 June 2014

Available online 15 July 2014

\section{Keywords:}

Dry bulk shipping

Maritime logistics

Haul lengths

Delphi survey

Long-term forecasts

\begin{abstract}
A B S T R A C T
This paper aims to synthesize the perceptions of early career specialists regarding trends in dry bulk shipping flows to 2050, the ship type which generates the second highest total volume of carbon emissions. Specialists' insights have implications for formulating polices to manage global trade and shipping emissions. Established Delphi survey techniques achieved consensus in a novel long-term industrial context amongst international panelists with long-term industrial commitment, highlighting trends in drivers including Arctic ice melt, canal upgrades, piracy and mode splits. Globally, expected doubling of raw materials shipments to Western economies and quadrupling elsewhere will be partially offset by specialists' perceptions of shorter hauls. Moderate annual expected tonnage growth globally compares with rapid annual growth in coal shipments, although more localized and multi-sourcing will shorten global coal hauls. After 2030, ocean routing is expected to slightly shorten global hauls. Climate change brings both Arctic ice melt with shorter expected average hauls from Northeast Asia to Western Europe and longer hauls elsewhere as more droughts and failed states force ship re-routing to avoid piracy. Canal upgrades will offer shorter average hauls. Within the UK rising expected demand for biofuels and intolerance of fossil fuels will reduce shipping demand, inviting investigation of a systems approach to planning.
\end{abstract}

(c) 2014 Elsevier Inc. All rights reserved.

\section{Introduction}

Increasingly, the sustainability of global trading systems including international shipping is being questioned (Lun et al., 2013; Lai et al., 2012). In particular recent concerns regarding the level of carbon dioxide emissions emitted by ships have heralded measures to regulate their design and operation to reduce emissions. Predictions of global shipping

Abbreviations: CAR, compound annual rate; ECA, Emission Control Area; kdwt, thousand deadweight tonnes; Mtpa, million tonnes per annum; N.E., Northeast; N.W., Northwest; R1, round one; R2, round 2; s.d., standard deviation; W., West.

* Corresponding author at: International Shipping and Logistics Group Leader, Plymouth Graduate School of Management, Plymouth University, Drake Circus, Plymouth, Devon PL4 8AA, UK. Tel.: + 441752 585611; fax: + 44 1752585713.

E-mail address: jdinwoodie@plymouth.ac.uk (J. Dinwoodie). flows to 2050 underpin forecasts of their likely environmental impacts, particularly emissions, and hence policy debates to develop technologies and operational strategies to manage and regulate them. In an industry suspicious of long-term forecasts which favors prediction to clarify risk rather than to create certainty (Stopford, 2009) awareness of the perceptions of panelists with long-term industrial commitment is integral to long-term planning. Accordingly, this paper aims to investigate the perceptions of early career specialists concerning trends in global dry bulk shipping flows up to 2050 for the ship type which generates the second highest total volume of carbon emissions (Buhaug et al., 2009). A complex industrial context embracing ships, flows, markets and particular commodities is introduced before detailing items for debate and the research challenge.

The ships which carry dry bulk goods are fashioned by market requirements and canal or port draft restrictions 
leading to arbitrary vessel size taxonomies (Stopford, 2009; Kaluza et al., 2010; DfT, 2009; Laulajainen, 2006a). Long hauls typically take place in Capesize vessels which carry cargoes exceeding $120 \mathrm{k}$ deadweight tonnes (dwt). Vessel repositioning and awaiting available berth space may engender port delays but many ports become inaccessible due to draft, quayside, storage or handling restrictions. If lightering operations are required to service for example many US East Coast ports they reduce scale economics, raise costs or make visits uneconomic. Very large bulk and ore carriers are severely restricted in the number of ports which can service them but popular sizes include 120, 150 and 175 kdwt. Many vessels exceed the current Panama Canal size limitations pending enlargement expected around 2015, but offer some scale economies while forfeiting time and distance savings on many routes compared with Panamax vessels capable of transiting the Panama Canal fully laden (60-85 kdwt.). Supramax vessels (45-65 kdwt) typically suit short and medium hauls often engaging draft-restricted ports. Handymax (35-45 kdwt) and Handysize vessels (15$35 \mathrm{kdwt}$ ) are sufficiently flexible to serve a wide range of market and port requirements. Smaller coastal vessels are typically excluded from international shipping analysis. Other taxonomies may highlight single or double skin hulls (DfT, 2009; Tamvakis and Thanopoulou, 2000) or commodity carried (Stopford, 2009).

Major dry bulk flows of coal, iron ore, grain, bauxite/ alumina and phosphates (Marlow and Gardner, 1980) exceed flows of cement, mineral sands, sulfur, timber and other cargoes classed as minor bulk trades. Demand for shipping reflects global economic activity and rising demand for industrial raw materials and energy commodities and the dynamic role of shipping in moving raw materials or semi-processed goods in fluctuating supply chains. Reducing transportation costs, global trade liberalization, diffused industrial processes, and port expansion have contributed to burgeoning seaborne movements (Alizadeh and Nomikos, 2010). As increasing tonnages lifted travel further, shipping demand expressed in tonne-km (tkm) (Stopford, 2009) and sometimes described as freight work (Mander et al., 2012) increases. Market segmentation reflects differing ship sizes, geographical routes and increasingly, quality factors. Intense competition precludes individual charterers from influencing freight rates creating an "atomistic competition" market structure (Laulajainen, 2006a, 2006b). Market information is accessible although some barriers delay market entry and exit. Further, seasonal factors influence charterers' demand for ship space driven by winter heating needs and grain harvests. Seasonal spot rate variability for larger vessels exceeds variability for smaller vessels but longer contract durations counter the effect (Kavussanos and Alizadeh, 2001).

Academic interest in dry bulk commodities has typically related to optimal sourcing and loading strategies (Shih, 1997; Bilgen and Ozkarahan, 2007). Early fully specified structural modeling of dry bulk shipping markets (Beenstock and Vergottis, 1993) has been replaced by models of particular ship types (Glen, 2006) and modeling of particular segments (Scarsi, 2007; Lun and Quaddus, 2009). Long-term forecasts of industrial production requirements, typically scenario-based, underpin most predictions of the likely future requirements to transport dry bulk goods. In recent models the demand for ships typically varies with the world economy, seaborne commodity trades, average haul, political events and transport cost. Ship supply varies with world fleet, fleet productivity, shipbuilding production, scrapping, losses and freight rates (Stopford, 2009). The size of ships depends on the requirements of particular trades and routes. Capesizes usually carry iron ore and coal, Panamaxes carry coal and grain and Handysizes carry grain and fertilizer (Laulajainen, 2006a), but markets are not discrete and chartering of two Panamax vessels may cost less than one Capesize vessel. Within the various markets, demand and ship size increase the uncertainty (Engelen et al., 2007). Pressures to invest in new ships may stem from funding instruments such as private equity or improved hedging instruments but the high risk and expense of investment in new buildings are often associated with a well-established shipping cycle upswing. At such times prudent owners possess sufficient retained earnings and imprudent lenders acquire the irrational exuberance required to place orders. New build berths expand to spawn ships which, with a five year delivery lead time, later increase the supply years after the market has peaked when demand is plunging. If acting rationally, shipowners would then scrap old ships, but being optimists, they prefer to await an upturn. Supply and demand may remain out of kilter for many years. Longer term, concern relating to structural failure in aging single-hull vessels promulgated increasing demands for newer and safer ships (Tamvakis and Thanopoulou, 2000). Scrappage rates influence the demand for vessels, and ship life span may influence shipping cycles (Bijwaard and Knapp, 2009). Influences on short-term supply include operational decisions relating to slow steaming or consuming alternative fuels which may influence available fleet capacity (tkm) and operating costs.

Patterns of dry bulk flows reflect regional surpluses and deficits for specific products and coal as the largest UK flow and second largest globally is a useful case-study. Despite predicted global coal production increases from 4 Bt in 2004 to $7 \mathrm{Bt}$ in 2030 comprised of $5.2 \mathrm{Bt}$ steam or thermal coal to fuel power stations, 0.6 Bt coking coal used in steel production and $1.2 \mathrm{Bt}$ of brown coal, only $18 \%$ of hard coal production was traded internationally in 2004 (W.C.I., 2005). Coal from South Africa, Australia, South America and Canada flows to Japan, China, the US and Europe. Steam coal will continue to fuel two-fifths of global electricity production until 2030. With a low value to weight ratio, coal is sensitive to transportation cost changes which contribute a significant share of total delivered price, and fuel costs typically explain $24 \%$ of raw material maritime transport costs (Korinek and Sourdin, 2009). To minimize transportation distances regionalized sourcing has created distinct Atlantic and Pacific markets. Western European importers include the UK, Germany and Spain, served by the Americas, South Africa, Russia and Australia. Pacific importers include Japan, Korea and China served from Australia, Indonesia and South Africa. In 2007 , coal fuelled $81 \%$ of electricity generation in China, $68 \%$ in India, and 49\% in the USA and Germany (W.C.I., 2009). As a high cost commodity, coking coal can bear high freight rates of exporting from Australia (51\% of world exports), North America and China (W.C.I., 2005). Rising household 
incomes in developing Asian countries will increase demand for electricity and steel use in construction, car production, and household white goods. Similar analysis could be reported for iron ore, sourced from South America or grain which flows from Russia and the US to India, Africa and increasingly China. Tracking bulker flows is problematic as vessel output measures span movements in national waters, number of vessel arrivals and tonnage loaded at national ports (Gilbert et al., 2010). Further complications arise from transhipment as ships are requested to load more cargoes on each trip (Chen et al., 2010) or reroute to avoid Emission Control Areas (ECAs) (International Maritime Organization, 2012) established to reduce local maritime atmospheric emissions.

Section 2.1 of this paper summarizes items for debate relating to shipping demand and hauls (I1:I8) which were identified in trade press literature reviews and invite evaluation by early career specialists. Section 2.2 presents the research challenge. Section 3 considers methodological issues relating to a Delphi survey of early career specialists' perceptions concerning trends in dry bulk shipping flows to 2050 including validity issues, instrument design and panel selection. Perceptions of global demand, haul lengths and UK hauls are analyzed in Section 4. Section 5 discusses the significance and limitations of findings before concluding.

\section{Some items for debate}

\subsection{Global and specific demand and haul lengths}

Items for debate include global and specific issues relating to shipping demand and haul lengths. Global demand for dry bulk shipping is a useful starting point. Global dry bulk shipping tonnage trebled in 1978-2007 (Hammer, 2009), but how will it change in the future (I1a, I1b)? As a major dry bulk shipping flow, coal has reserves estimated to last 122 years and is easy to store with low obsolescence, but incurs high inventory costs (W.C.I., 2005). Will coal shipments globally still grow at $8 \%$ compound annual rate (CAR) (I1c, I1d)? Given dematerialization and reducing energy intensities the energy used per unit of output is declining, but by 2050 if shipments of raw materials to industrialized Europe and North America double, what will happen elsewhere (Osler, 2010; Smyth et al., 2012) (I1e, I1f)? Transport accounts for a large share of delivered unit price for many dry bulk goods (W.C.I., 2005) and tonnage shipped is influenced by shipping cost changes. But how responsive are, for example, coking and steam coal freight rates to bunker fuel price hikes in the short and long run (I2)?

Measures of shipping demand or freight work (tkm) combine both tonnage lifted $(\mathrm{t})$ and distance hauled $(\mathrm{km})$ and changes in both elements affect demand. Thus rising global freight work may reflect either longer hauls as local material sources are exhausted or output increases. Economic growth raises shipping demand but technical advances, which reduce the energy and materials intensities of production processes and thus energy and materials requirements per unit of output, reduce demand. The sole impacts of Arctic ice-melt, which creates new routes, canal improvements, or vessel efficiency initiatives on haul lengths and hence shipping demand, are debatable (International
Maritime Organization, 2012) (I3). Similarly, competition from modes such as rail may impact mode-shares and shipping demand (I4).

Controversial drivers of global average hauls may include tendencies to regionally source bulky materials such as coal to reduce bunker costs (Hammer, 2009) (I5a), re-routing to avoid regulated areas (I5b, I5c) or reduce emissions (I5d, I5e) and multi-sourcing of materials for security reasons (W.C.I., 2005; I5f). To encourage improvements in the fuel consumption of new ships the International Maritime Organization introduced an Energy Efficiency Design Index [International Maritime Organization, 2012; MEPC.1/Circ.681]. This requires a minimum energy efficiency level for new ships and promotes technical development by enabling a comparison between similar individual ships. For ships in operation an Energy Efficiency Operational Index compares the energy efficiency of a specific ship against others of its type. A Ship Energy Efficiency Management Plan incorporates best practice relating to voyage planning, optimal speed, power and handling, cargo handling and fleet and energy management. Regulations also influence the type of fuel which ships may consume. In May 2005, to regulate the mass/mass of sulfur content for marine fuel oil to control sulfur oxide emissions from ships, Sulfur ECAs were designated (International Maritime Organization, 2012). ECAs in the North Sea, Baltic Sea and North America cost-effectively cut ship-originated air pollution (Wang and Corbett, 2007) and were extended to include other emissions. Unknown future ECA designations may influence ships to re-route to avoid them or incur higher costs to ensure compliance. EU regulatory pressure and local ECA designations will favor movements in intra-European waters which minimize emissions. Market based carbon reduction measures involving perhaps a bunker-fuel levy may accelerate trends towards local sourcing, pipeline transportation and reduced demand for energy and raw materials.

Globally, specific haul lengths may be impacted by Arctic passages, canal upgrades and piracy (I6a:I6e) (Parsons et al., 2011; Stott and Wright, 2012; Verny and Grigentin, 2009). UK-centric import haul lengths may equally be impacted by localized sourcing, piracy and regulatory measures (I7). To achieve commitments to reduce UK carbon dioxide emissions by $80 \%$ by 2050 , mitigation policies associated with various future scenarios for UK shipping have been proposed (Mander et al., 2012; Committee on Climate Change, 2011) (UK Committee on Climate Change, 2011) and energy reduction commitments (Department of Energy and Climate Change, 2011) are challenging. Estimates (Mander et al., 2012) indicate that in 2006 coal generated 60\% of UK shipping's freight work but only $24 \%$ of total carbon dioxide emissions, with transportation predominantly in Capesize bulkers which achieved scale economies and were fuel efficient. Two scenarios identified to reduce energy emissions by 2050 include focus on Renewables based on "higher energy efficiency, more renewable energy" and "higher carbon capture and storage, more bioenergy" (Department of Energy and Climate Change, 2011). By 2050, estimates (Mander et al., 2012) imply that the Renewables scenario entails 53\% reduction in per capita energy demand, with greater use of electric cars and public transport, 55\% of energy supply from renewables, and $75 \%$ reduction in 
shipping freight work. The Carbon Capture and Storage scenario implies $44 \%$ reduction in shipping freight work. By 2050 domestically produced coal will satiate 1\% and 5\% respectively under Renewables and Carbon Capture and Storage scenarios of UK primary energy demand reducing from $34 \%$ in 2010 , mainly imported. Forecast biomass shares rise from $3 \%$ in 2010 to $15 \%$ and $27 \%$ respectively generating import demands of 6 Mtpa and 13 Mtpa (Mander et al., 2012). The UK Committee on Climate Change (2011) presented demand scenarios for UK cargo predictions up to 2050 which included central tonnage demand growth of $0.1 \%$ CAR, low demand of $-0.6 \%$ CAR and high demand of $0.5 \%$ CAR. Given UK commitments to decarbonize, coal usage as a fossil fuel was predicted to reduce rapidly, ores to flat-line, "other dry bulks" to follow historical trends but biomass imports to grow rapidly. The extent to which expansion and local sourcing of alternative energy sources including biofuels (I8a-I8d) (Pätäri et al., 2011) or carbon capture and storage (I8e) will impact demand for bulkers is debatable. Other controversies include how far the UK as an advanced industrial nation may accept systemic post-oil dependence behavioral shifts including intolerance of fossil fuels (HM Treasury, 2006) (I8f), dematerialization of the economy (I8g) and the number of bulk terminals (I8h).

\subsection{The research challenge}

To investigate the issues identified presents a significant research challenge. Detailed modeling of shipping emissions and the effectiveness of potential regulatory and operating procedures to mitigate them is predicated by realistic estimates of the future demand for shipping, but secondary data is limited. Sources including the UK government and supranational and private statistical sources such as Clarksons Shipping Information Network were deployed to identify baseline dry bulk flows in 2010 (Dinwoodie et al., 2011). This work independently supplements a larger study (Smith et al., 2010) which incorporated a synthetic quantitative shipping systems model based on trends, external trade forecasts by non-maritime specialists, and scenarios (Smith and O'Keeffe, 2013; Lloyd's Register, 2013). To supplement, validate and triangulate statistical trend based modeling, this study aimed to canvas early career specialists' perceptions of future dry bulk shipping flows based on foreseeable scenarios of demand to 2050. Determinants of demand include demand for total freight transport, dependent on population and Gross Domestic Product growth, production and location decisions; sourcing policies; length of haul; and maritime mode shares, partially dependent on sensitivity to shipping costs including bunker prices (Stopford, 2009). To tap specialist expertise a Delphi panel offers one research strategy to gather data to directly probe debatable items (I1:I8).

Stakeholder views of the future demand for shipping include the owners, managers and operators of ships; managers of ports and logistics systems; brokers, consultants, classification societies, insurers and regulators in shipping; and specialist researchers and practitioners in logistics and supply chain management. No individual can comprehend the totality of this complex interconnected system, and complex issues color each individual's conceptualizations of emerging trends and prospects. To canvass specialists' opinions and probe perceptions of emergent issues which affect future demand a survey technique capable of generating consensus is required. In a Delphi panel, experts communicate in a structured way which assists researchers in understanding the implications of changing operational environments for all stakeholders. Rapid change, uncertainties and complex and multifaceted implementation issues demand a multidisciplinary perspective which engages diverse experts knowledgeable about the problem area. Delphi techniques assist researchers to capture wide-ranging interrelated variables and multidimensional features of complex problems (Gupta and Clarke, 1996) in a questionnaire tailored to the immediate study objectives which can accommodate asynchronous responses and geographically dispersed participants (Lynch et al., 1994). Delphi methods have been extensively applied in business and transportation incorporating elements of qualitative and quantitative research (Islam et al., 2006; Ariel, 1989; Dinwoodie et al., 2013). Aside from forecasting (Linstone and Turoff, 1975) applications suit gathering data which is not accurately known or available, exploring planning options, assessing potential policy options and developing causal relationships in complex economic or social phenomena including organizational effectiveness (Cetin and Cerit, 2010) and multimodal integration (Makukha and Grey, 2004). Numerous other applications include logistics service provision (von der Gracht and Darkow, 2010), the carbon footprint of road transport (Piecyk and McKinnon, 2010) and supply chain risk management (Markmann et al., 2013). Interestingly, small panel sizes in the maritime sector, numbering 8 (Ariel, 1989), 13 (Islam et al., 2006) and 35 in recent work similar to this study (Dinwoodie et al., 2013) may reflect fewer specialist organizations than in related logistics and supply chain contexts.

Because the situational research design of Delphi studies is guided by research objectives rather than prescribed methods, assessments of study quality depend on how a particular design drawn from a diversity of applications is executed (Hasson and Keeney, 2011; Landeta, 2006). Although multifarious Delphi designs have been developed, taxonomies typically identify a "Classic" Delphi, designed to canvass opinions and achieve consensus (Nowack et al., 2011); or a "Policy" Delphi, developed to solicit opposing views (Turoff, 1970) which can be extended to distil these views into arguments, sometimes discussed in detail in groups. Variants include the disaggregative policy Delphi (Kuusi and Meyer, 2002; Tapio, 2002) which can be used to develop scenarios. In approaches where online feedback is collected in real time, numerous iterations become feasible (Steinert, 2009). The next section outlines the preferred methodology for this work.

\section{Methodology}

Because elements of Delphi studies are interpretative, the credibility and trustworthiness of the research processes adopted merit comment. Credibility is established through iteration but to assess confirmability, details of data collection and analysis procedures are presented. Dependability relates to panel selection and transferability is established 
when findings are verified. This section reports how two rounds of Delphi (R1, R2) were conducted, how the Delphi instrument was derived, and how panelists were selected. Of the numerous Delphi designs available (Hasson and Keeney, 2011) a classic quantitative design was selected as being most appropriate to achieve the prime objective of synthesizing perceptions. Delphi designs typically aim to ensure anonymity, controlled feedback, iteration and participating experts (Linstone and Turoff, 1975; Landeta, 2006; Nowack et al., 2011). To avoid developing bandwagon effects whereby one individual or viewpoint may come to dominate or influence others, each panelist remains anonymous, denying intra-panel communication. In this design, the mean R1 response on each statement was fed back to panelists who were offered an opportunity to revise their initial evaluation in $\mathrm{R} 2$, ending the natural cycle of evaluation. The breadth of issues in R1 suffices to reveal general perceptions offering a low marginal value from raising additional issues in further rounds, and the value and expected number of "responses to revised responses" would be minimal. Interestingly two rounds often suffice in maritime Delphi applications where participants receive few practical rewards, creating fears of participant fatigue (Islam et al., 2006; Dinwoodie et al., 2013; Cetin and Cerit, 2010; Makukha and Grey, 2004; Song and Lee, 2012).

Delphi processes also impinge on issues of validity and reliability, the traditional hallmarks of positivist research. In this study, which is replicable, assurances of the internal validity of the content, constructs and criteria deployed match considerations of generalizability and external validity. Based on drivers of future shipping flows identified in trade press articles and academic opinions, an R1 instrument was devised to test for consensus regarding future market trends, ensuring content-coincidence with the object of study. However, because panelists did not generate these Delphi statements the validity of the constructs evaluated is not grounded in their expertise. Consequently all statements offered an "unable to comment" option, also ensuring that participation was voluntary. To ensure criterion validity statements must correlate with an evaluation, which may be compromised by high drop-out rates. To enhance their awareness of this, panelists in R2 were informed that non-return would be assumed to represent confirmation of their R1 choices. Regarding external validity, panelists' perceptions are inevitably temporally idiosyncratic, but short-term market distortions have limited influence on long-term perceptions (Piecyk and McKinnon, 2010). Further, the likelihood of achieving generalizability was maximized by recruiting a committed panel of diverse early career specialist stakeholders embracing multiple nationalities and disciplines.

Data extracted from recent articles in the shipping trade press spanning socio-economic, shipping and shipping markets and political drivers were refined into draft statements which were circulated and tested amongst eight specialists in four universities regarding their suitability for inclusion in a Delphi survey. If feasible to canvass, academics favored quantitative perceptions by early career specialists of developments from 2010 to 2030 (period $\alpha$ ), and from 2030 to 2050 ( $\beta$ ) rather than from 2010 to 2050 ( $\eta)$. Following further refining of statements a pilot Delphi panel was convened to test a draft online Qualtrics survey instrument. In general, respondents were offered a modified Likert scale on which to respond to quantitative statements about their perceptions of developments for periods $\alpha$ and $\beta$, which included an 'unable to comment' response. In pilot surveys few respondents attempted all questions indicating a need to shorten the instrument. Further because many respondents were "unable to comment" on $\beta$ comparisons, many $\alpha$ and $\beta$ evaluations were merged to $\eta$. Questions which requested estimates of voyage lengths explicitly requested estimates "averaged over all relevant routes, ship sizes and types." When estimating tonnages, elasticities and proportions, operationally significant groupings within 25,50 and $67 \%$ of a central estimate were canvassed and reduced to 10, 20 and $30 \%$ for global demand, and 10, 25 and 35\% for voyage length estimates. These indicative class intervals generated assumed midpoints (Table 1) which facilitated calculation of mean estimates. Because concepts of growth rates and elasticities are fundamental to business planning by maritime specialists and required knowledge on university courses and for membership of the Chartered Institute of Shipbrokers, piloting revealed no concerns in evaluating estimates of them.

Panel selection aimed to ensure that interested and knowledgeable early career specialists represented multidisciplinary stakeholder interests and viewpoints (Czinkota and Ronkainen, 1997). To ensure long-term instrumental industrial commitment to a 2050 planning horizon and minimize noncommitment bias (Fowkes and Preston, 1991), early career professionals were recruited alongside an international group undertaking specialist postgraduate studies of the complex and interrelated drivers of shipping demand. Although dry bulk represents a coherent maritime sector, it embraces individuals with diverse expertise and interests in terms of the commodities and ship sizes they engage with, their skill-sets and their precise stage and role in the supply chain. Panel selection sought to represent this diversity. All post-graduate panelists were "early career specialists". Given the specialist industrial nature of the courses represented, even participants lacking prior full time industrial experience are deemed by the accrediting professional body to have acquired two years of equivalent industrial experience. Additionally 32.5\% and $22.5 \%$ respectively had worked for at least one year in relevant supply chain management and shipping environments. As specialist maritime postgraduates, each one has made a personal career investment decision to specialize in and to fund attendance on a maritime course, and to forgo earnings to do so. Given the wide-ranging study objectives, relatively few practitioners will have the time to reflect on recent economic and policy issues or possess the current broad overview and inter-corporate perspectives of industrial awareness which a current postgraduate program offers to participants. Prior to participation all postgraduate recruits had recently been required to research and present a detailed report on bulk developments in the maritime sector; to complete a course in advanced Maritime Economics; and to attend presentations by leading practitioners.

Given that the "shipping industry" is notoriously conservative, perhaps reflecting the huge fixed capital invested in ships and the levels of risk encountered, it has been observed to resist change until major industrial shocks occur, which then trigger a "herding instinct" (Stopford, 2009). Given their knowledge of the industry and a 2050 time horizon, the eight academic advisers recommended a panel of knowledgeable 
Table 1

Item levels, assumed midpoints and categories.

\begin{tabular}{|c|c|c|c|c|c|c|}
\hline Item & Level & Category & & & & \\
\hline \multirow[t]{2}{*}{1,2} & Level & $>50 \%$ too high & $25-50 \%$ too high & About right & $25-50 \%$ too low & $>50 \%$ too low \\
\hline & Midpoint & 0.60 & 0.73 & 1.00 & 1.37 & 1.67 \\
\hline \multirow[t]{2}{*}{3} & Level & Fall $>20 \%$ & Fall 10-20\% & Change little & Rise $10-20 \%$ & Rise $>20 \%$ \\
\hline & Midpoint & 0.70 & 0.85 & 1.00 & 1.15 & 1.30 \\
\hline \multirow[t]{2}{*}{$5,6,7$} & Level & $>25 \%$ shorter & $10-25 \%$ shorter & Change little & $10-25 \%$ longer & $>25 \%$ longer \\
\hline & Midpoint & 0.70 & 0.85 & 1.00 & 1.175 & 1.30 \\
\hline \multirow[t]{2}{*}{4,8} & Level & Fall $>50 \%$ & Fall $25-50 \%$ & Change little & Rise $25-50 \%$ & Rise $>50 \%$ \\
\hline & Midpoint & 0.60 & 0.73 & 1.00 & 1.37 & 1.67 \\
\hline
\end{tabular}

and specialist committed individuals, comprised of both a broad range of practitioners and early career maritime specialists likely to be more amenable to embrace change. Early career specialists will typically be committed to maritime careers throughout the target period up to 2050, unlike many senior executives with expectations of retirement long before 2050 who might, in the longer term, exhibit non-commitment bias. The blend of specialists was selected to ensure that an appropriate range of stakeholders is represented. All panelists were knowledgeable about dry bulk shipping flows and were recruited for their specialist professional or postgraduate level academic knowledge. Panel membership was by invitation only, to avoid any self-selection bias. Membership pages of the Institute of Chartered Shipbrokers provided an initial sampling frame of organizations engaged in relevant flows and typically the head of either dry bulk or research was invited to join a Delphi panel. To broaden the stakeholder interests represented, further personal contacts were added. In total, of 89 practitioners that were emailed in December 2011, four completed the online Qualtrics Survey software R1 survey. A more succinct instrument was devised, and after two of the initial group became incommunicado, a reminder was emailed to 87 practitioners in mid-February which generated seven further responses. Invitations were emailed to international postgraduate students at Plymouth University in December 2011 and following repeat invitations to 85 International Shipping and Logistics Masters students in January and February, 40 completed the R1 instrument to supplement the 11 industrialists. Because email is flexible, is convenient and enables a message to engage a recipient who can respond when convenient bespoke $\mathrm{R} 2$ questionnaires were emailed to R1 respondents as MS Word attachments. The overall invitation to participation rate of 3.4 exceeds average rates of 4.4 (Nowack et al., 2011). Practitioner panelists included a maritime consultant, head of research at a large shipbroker, a professor, a senior broker, a senior market analyst, a director of a classification society, two bulk shipping specialists, an insurance underwriter and two logistics coordinators. When combined with postgraduates' specializations, panelists' specialist interests comprehensively spanned dry bulk shipping, logistics and supply chain management (Table 2), representing four continents, and a broad range of cargo types and ship sizes. Mean estimates were fed back to panelists in R2 alongside an opportunity to revise their individual initial opinions.

Non-parametric independent samples Mann-Whitney $U$-tests were conducted to test for differences in the central tendency of the distributions of responses between various sub-groupings. Visual inspection of histograms of each variable for all sub-groups typically revealed normal distributions, but non-parametric comparisons with slightly reduced inferential power were selected to ensure consistency across all variables (von der Gracht, 2012). Because comparisons of practitioner and postgraduate subgroups revealed significant differences $(p<0.05)$ on only two statements no further disaggregation of panel responses is appropriate. In a further test for consistency between early and late respondents the first quartile of early responses was compared with the last, who having received additional reminders, may exhibit similar characteristics to non-respondents (Piecyk and McKinnon, 2010). A null hypothesis of no difference was rejected $(p<0.05)$ on only two statements again indicating that non-response bias in the Delphi panel is very unlikely.

It is conceivable that if panelists have shared similar experiences their responses may be biased. For example if postgraduate groups have attended the same presentations and lectures, their responses may indirectly reflect the views of lecturers and presenters. We briefly explore this proposition. A course in research skills and economics for international supply chains which underpinned postgraduates' recent relevant experiences aimed "to foster critical awareness of the economic and other contexts framing international supply chain decisions". To achieve this objective, participants were offered multiple learning experiences. Diverse postgraduate panelists included 13 taught partially in the Netherlands alongside recruits from Belgium, Germany and Far East Asia, and 27 in the UK, drawn from around the world. Three Dutch lecturers introduced the first group to local visits and practitioners and requested literature reviews of relevant topics. Their external examiner noted: "An impressive range of topics identified. It is clear that the students' own research interests and career paths are instrumental in choosing topics." In the UK, three lecturers exposed participants to UK, European and global statistical sources on transport and energy, reports from the Independent Panel on Climate Change, three major ship brokers, oil companies, professional industry trade associations and corporate sources. Six visiting industrialists offered multiple and diverse perspectives, with participants choosing whether to attend. Written work included instructions to assess the contribution, ethics and assumptions underpinning these sources in tackling the question "How will maritime flows of one specific bulk commodity into, out of, and within the UK, change up to 2050?" Later, after both postgraduate groups combined they were offered ten further practitioner presentations and required to explore how and why the major sources of supply, demand and transportation for one selected commodity will change from 2010 to 2050. Participants from 
Table 2

Profile of panelists.

\begin{tabular}{|c|c|c|c|c|}
\hline Trait & Group & $\%$ & Group & $\%$ \\
\hline \multicolumn{5}{|l|}{ All panelists } \\
\hline \multirow[t]{3}{*}{ Nationality } & Non-UK Europe & 42 & Africa & 6 \\
\hline & Asia & 34 & North America & 2 \\
\hline & UK & 16 & & \\
\hline \multirow[t]{4}{*}{ Profession } & Logistician & 26 & Port manager & 6 \\
\hline & Miscellaneous supply chain & 26 & Energy & 6 \\
\hline & Researcher & 16 & Government or regulation & 4 \\
\hline & Shipbroker & 12 & Shipowner & 4 \\
\hline \multirow[t]{2}{*}{ Cargo type } & Dry bulk & 36 & Various & 44 \\
\hline & Container & 20 & & \\
\hline \multirow[t]{3}{*}{ Ship size } & Various & 44 & Handysize & 10 \\
\hline & Suezmax & 24 & Small (<10 kdwt) & 6 \\
\hline & Very large & 12 & Panamax (2011) & 4 \\
\hline
\end{tabular}

First and second commodity/sector specialisms of postgraduate panelists

\begin{tabular}{lrr}
\hline Commodity & First & Second \\
\hline Energy & 40.0 & 25.0 \\
Iron ore and steel & 25.0 & 7.5 \\
Coal & 15.0 & 12.5 \\
Grain & 10.0 & 5.0 \\
Biofuel & 5.0 & 5.0 \\
Other & 0 & 5.0 \\
Forestry & 5.0 \\
Supply chains & 0 & 32.5 \\
\hline
\end{tabular}

such diverse backgrounds who selected their own preferred sources and contexts for learning, research and assessment, imply few concrete common influences but if learning experiences have biased perceptions, significant differences would be expected between measures of central tendency of the distributions of responses of Dutch and UK groups. To test for this effect, non-parametric independent samples Mann-Whitney U-tests were conducted. A null hypothesis of no difference was rejected $(p<0.05)$ on only one out of 41 statements in each round indicating that learning experiences are very unlikely to have biased postgraduate responses. In summary, no significant differences were observed between practitioner and postgraduate groups, or between two postgraduate subgroups in different countries with different learning experiences. To test whether all maritime participants have been tainted by conservatism in their industry (Stopford, 2009) would require control group surveys involving other industries.

\section{Results}

\subsection{Global demand}

Both the mean and standard deviation (mean R1, mean $\mathrm{R} 2$, \% fall in s.d., Table 3 ) of panelists' considered estimates of freight demand growth for dry bulk shipping flows were less than for initial statements. Despite trebling of global dry bulk tonnage in 1978-2008 (3.73\% CAR), early career specialists' perceptions were lower (Table 3; $\alpha=2.126 \%$ CAR, $\beta=$ $2.181 \%$ ). Similarly although global coal shipments have grown recently at $8 \%$ CAR, expectations were slightly lower ( $\alpha=7.44 \%$ CAR; $\beta=7.2 \%$ ). Early career specialists predicted that demand for shipping raw materials to Europe and North America would rise by $89 \%$ from 2005 to 2050 (1.413\% CAR). However, panelists agreed that demand to locations outside Europe and North America would almost quadruple.

Estimates revealed early career specialists' perceptions that bunker price changes impact dry bulk spot freight rates substantially. The considered mean short run spot freight rate elasticity for coking coal in relation to bunker fuel prices was 0.95 with long run estimates of 0.92 (Table 4). Similarly the estimated short run spot freight rate elasticity for steam coal in relation to bunker fuel price rise was 0.534 . These results imply that, other things being equal, $95 \%$ of any short-term bunker fuel price rises are likely to be passed on in higher freight rates in coking coal markets which serve the steel industry and car markets, contributing to inflationary pressures or reduced demand. Further, any market based

Table 3

Delphi responses relating to global demand items.

\begin{tabular}{|c|c|c|c|c|c|}
\hline 1. How accurate are the following freight demand estimates? & Time & No reply & Mean R1 & Mean R2 & $\%$ fall in s.d. \\
\hline 1a. Global dry bulk tonnage will double in 30 years pro-rata from 2010 to 2030 . & $\alpha$ & 0 & 0.88 & 0.89 & 5 \\
\hline 1b. ....and from 2030 to 2050. & $\beta$ & 4 & 0.91 & 0.90 & 7 \\
\hline 1c. Global coal shipments will grow at 8\% a year pro-rata from 2010 to 2030 . & $\alpha$ & 1 & 0.93 & 0.95 & 3 \\
\hline 1d. ... and from 2030 to 2050 . & $\beta$ & 1 & 0.90 & 0.92 & 4 \\
\hline 1e. Demand for shipping raw materials to Europe and North America will double. & $\eta$ & 0 & 0.89 & 0.89 & 5 \\
\hline 1f. Demand for shipping raw materials to locations outside Europe and North America will quadruple. & $\eta$ & 0 & 1.00 & 0.99 & 4 \\
\hline
\end{tabular}


Table 4

Delphi responses relating to freight rate elasticities.

\begin{tabular}{|c|c|c|c|c|}
\hline $\begin{array}{l}\text { 2. How accurate are the following estimates of dry bulk freight rates changes in relation } \\
\text { to bunker price changes? }\end{array}$ & No reply & Mean R1 & Mean R2 & \% fall in s.d. \\
\hline $\begin{array}{l}\text { 2a. In the short run the spot freight rate for coking coal will double if bunker fuel prices } \\
\text { double in real terms. }\end{array}$ & 1 & 0.95 & 0.96 & 5 \\
\hline $\begin{array}{l}\text { 2b. In the long run the spot freight rate for coking coal will more than double if bunker } \\
\text { fuel prices double in real terms. }\end{array}$ & 0 & 0.92 & 0.89 & 13 \\
\hline $\begin{array}{l}\text { 2c. In the short run the spot freight rate for steam coal will rise by } 60 \% \text { if bunker fuel } \\
\text { prices double in real terms. }\end{array}$ & 3 & 0.89 & 0.91 & 4 \\
\hline
\end{tabular}

measures to reduce shipping emissions such as bunker fuel levies would have minimal impact on fuel consumption by ship operators, even in the long term. Conversely, given that many substitutes exist for steam coal, almost half of any bunker fuel price increases would have to be absorbed by ship operators, making this sector potentially much more responsive to market based measures.

Individual drivers in isolation have limited impact on total global dry bulk shipping freight work and indeed, taken together, may be almost self-compensating. An enlarged Panama Canal slightly increases demand $(\alpha=2 \%, \beta=1 \%$; Table 5) as marginally does Artic ice-melt ( $\alpha=1 \%, \beta=0 \%)$ which is more than offset by Energy Efficiency Design Index regulations which require ships to emit less carbon ( $\alpha=-2 \%$, $\beta=-4 \%$ ).

Numerous issues drive the modal split of China's coal imports, with China as the largest consumer and importer, and a major producer. Despite huge investment in rail hauls to Mongolia, impacts on the proportion of China's coal imports moved in ships is neutral $(\alpha=2 \%, \beta=-2 \%$; Table 6). This may reflect limitless coal supplies in Australia, expected shipments in low cost China-max bulkers, and uncertainty over the scale of rail investment.

\subsection{Global haul lengths}

Taken individually, no single driver was expected to radically impact average voyage lengths globally (Table 7 ). Shortening global coal hauls were expected due to multi-sourcing for energy security $(\eta=-4 \%)$ and localized sourcing as bunker costs rise $(\eta=-4 \%)$. Global dry bulk shipping hauls would shorten after 2030 due to ocean routing ( $\alpha=0 \%, \beta=-3 \%$ ) and ECA avoidance $(\alpha=0 \%, \beta=-1 \%$ ). Many advantages of expected shortening of specific average voyage lengths (Table 8) on N.E. Asia-West Europe hauls as Arctic ice melt creates a Canadian N.W. Passage $(\eta=-6 \%)$ and a Russian N.E. Passage $(\eta=-5 \%)$ would be offset by re-routing to avoid piracy caused by more droughts and failed states $(\eta=+8 \%)$. Expected hauls Northeast Asia-US East Coast shorten substantially due to an enlarged Panama Canal $(\alpha=-7 \%, \beta=-5)$.

\subsection{UK hauls}

Mean considered estimated sole impacts of drivers on the average lengths of UK dry bulk shipping flows were varied (Table 9). By 2050, any shortening due to rising bunker costs which favors regionalized sourcing $(\eta=-5 \%)$ would be reversed by re-routing to avoid piracy $(\alpha=+5 \%, \beta=$ $+3 \%)$ and ECAs $(\alpha=+4 \%, \beta=+2 \%)$ although with more localized sourcing lengthening may impact relatively few UK hauls.

Drivers of specified components of UK demand for dry bulk shipping flows in isolation had radical impacts (Table 10), as growth in biofuels was expected to significantly reduce UK demand for bulkers to import coal (tkm; $\alpha=-12 \%, \beta=-13 \%$ ) an effect slightly amplified by increasing UK self-sufficiency in biofuel production which reduces UK import demand for bulkers ( $\alpha=-1 \%, \beta=-4 \%$ ). Rising costs and requirements to capture carbon from coal fired power stations were expected to reduce UK demand for bulkers to import coal $(\eta=-4 \%)$ as was growing intolerance of UK society with using fossil fuels to produce energy $(\eta=-9 \%$ ). Dematerialization, associated with a reducing role for manufacturing in the UK economy would slightly reduce UK demand for bulkers to import raw materials $(\eta=-3 \%$ ), but the expected number of operational UK deep water dry bulk terminals would change little $(\eta=1.02)$.

Table 5

Delphi responses relating to sole drivers of global demand.

\begin{tabular}{|c|c|c|c|c|c|}
\hline $\begin{array}{l}\text { 3. How will solely the driver shown affect total global demand (tkm) for } \\
\text { dry bulk shipping? }\end{array}$ & Time & No reply & Mean R1 & Mean R2 & $\%$ fall in s.d. \\
\hline $\begin{array}{l}\text { 3a. Shorter sea routes due to Arctic ice-melt will cause total dry bulk tkm } \\
\text { from } 2010 \text { to } 2030 \text { to: }\end{array}$ & $\alpha$ & 2 & 1.01 & 1.01 & 2 \\
\hline 3 b. ....and from 2030 to $2050 \ldots$ & $\beta$ & 6 & 1.01 & 1.00 & 8 \\
\hline 3c. Enlarged Panama Canal will cause dry bulk tkm from 2010 to 2030 to: & $\alpha$ & 1 & 1.04 & 1.02 & 10 \\
\hline $3 d . .$. and from 2030 to $2050 \ldots$ & $\beta$ & 5 & 1.04 & 1.01 & 7 \\
\hline $\begin{array}{l}\text { 3e. Energy Efficiency Design Index regulations which require ships to emit } \\
\text { less carbon will cause dry bulk tkm from } 2010 \text { to } 2030 \text { to: }\end{array}$ & $\alpha$ & 0 & 0.96 & 0.98 & 3 \\
\hline 3f. ....and from 2030 to $2050 \ldots$ & $\beta$ & 2 & 0.96 & 0.96 & 5 \\
\hline
\end{tabular}


Table 6

Delphi responses relating to mode of China's coal imports.

\begin{tabular}{llrr}
\hline $\begin{array}{l}\text { 4. Solely because of improved rail links to haul coal from Mongolia } \\
\text { to China the \% of China's coal imports carried in ships may change. }\end{array}$ & Time & No reply & Mean R1 fall in s.d. \\
\hline 4a. The \% in ships from 2010 to 2030 will: & $\alpha$ & 0 & 1.01 \\
4b. ....and from 2030 to $2050 \ldots$ & $\beta$ & 2 & 1.00 \\
\hline
\end{tabular}

\section{Discussion}

\subsection{Study limitations}

All behavioral forecasts, including Delphi approaches are prone to methodological criticism (Stopford, 2009). One observation posits that respondents may prefer to offer precise answers which although wrong, might appear more authoritative than vague but more accurate answers. To counter this effect no precise response categories were offered in this work. To combat non-commitment bias (Fowkes and Preston, 1991) Delphi panel recruitment targeted many early career specialists, likely to be committed to this industry for most of the study period. Bias which may arise from short-termism and inappropriate myopic projection of current events into a normative long-term contextualization was reduced by excluding statements about short-term developments in this instrument. In some circumstances, similarities in specialists' predictions may reflect apparent but incorrect consensus, attributable to universal uncertainty. If such a situation attains in this work, it would merely endorse the complexities of long-term forecasting in volatile markets where expressions of certainty would be irrational. Overall, the Delphi methods deployed succeeded in generating useful estimates of long-term market developments independently of medium term trend based statistical predictions. By ensuring recruitment of a panel likely to remain industrially committed throughout the study period the results represent the specialist perceptions of a diverse, knowledgeable and committed group of future practitioners.

\subsection{Some policy implications}

Policy issues consequent on predictions of substantial growth in dry bulk tonnages lifted by 2050 partially offset by perceptions of shorter hauls include fleet expansion and scope for Energy Efficiency Design Index measures to ensure a stock of low carbon bulkers. Drivers such as increased biofuels consumption and localized production, and dematerialization of advanced economies will tend to reduce shipping demand and counterbalance growth in the shipping freight work required to serve developed economies. Consequently carbon emissions will grow less quickly. Measures to tackle piracy also proffer reductions. Overall, if global shipping demand doubles three decades hence rather than trebling as occurred previously, carbon emissions will also grow less rapidly. However, global demand will increase, even for coal, to satiate raw material demands in rapidly developing economies. Despite increasing dematerialization of more economies, ongoing research into reducing energy intensities and raising the technical efficiency of production to minimize raw materials input is urgently required. Although freight rates are estimated to respond elastically to bunker price changes, this analysis ignores cost pass-through considerations where substantial rises in delivered unit prices may drive a search for alternative fuels to thermal coal, or non-metal material substitutes to steel for car making. Further, in this analysis, Energy Efficiency Design Index regulations alone were expected to reduce total global freight work slightly, although coal hauls will also shorten slightly due to localized and multi-sourcing. New Arctic passages caused by ice-melt will shorten N.E. Asia-W. Europe mean hauls, and even if increased piracy threats lengthen hauls in the Indian Ocean, this impacts a reducing proportion of hauls. International agreements to manage Arctic developments sustainably and tackle piracy could significantly reduce shipping's carbon emissions.

Regarding UK hauls, perceptions of slight reductions in haul length due to rising bunker costs offset by increased re-routing to avoid ECAs and piracy imply a dwindling source of quick win-win carbon reduction operational strategies. The broadly neutral haul length expectations presented here

Table 7

Delphi responses relating to global voyage lengths.

\begin{tabular}{|c|c|c|c|c|c|}
\hline $\begin{array}{l}\text { 5. How will solely the driver shown affect the global average voyage } \\
\text { length of dry bulk hauls }(\mathrm{km}) \text { ? }\end{array}$ & Time & No reply & Mean R1 & Mean R2 & \% fall in s.d. \\
\hline $\begin{array}{l}\text { 5a. Rising bunker costs by favoring sources close to demand locations } \\
\text { will cause global average coal bulker hauls }(\mathrm{km}) \text { to be: }\end{array}$ & $\eta$ & 1 & 0.95 & 0.96 & 10 \\
\hline $\begin{array}{l}\text { 5b. More ship re-routing to avoid more Emission Control Areas will } \\
\text { cause global average dry bulk hauls (km) from } 2010 \text { to } 2030 \text { to be: }\end{array}$ & $\alpha$ & 2 & 0.99 & 1.00 & 14 \\
\hline 5c. .... and from 2030 to $2050 \ldots$ & $\beta$ & 5 & 0.97 & 0.99 & 8 \\
\hline $\begin{array}{l}\text { 5d. Ocean Routing and operating measures to reduce carbon emissions will } \\
\text { cause global average dry bulk hauls }(\mathrm{km}) \text { from } 2010 \text { to } 2030 \text { to be: }\end{array}$ & $\alpha$ & 1 & 0.97 & 1.00 & 14 \\
\hline 5e. .....and from 2030 to $2050 \ldots$ & $\beta$ & 3 & 0.97 & 0.97 & 10 \\
\hline $\begin{array}{l}\text { 5f. Multi-sourcing to secure energy supplies will cause global average } \\
\text { coal bulker hauls }(\mathrm{km}) \text { to be: }\end{array}$ & $\eta$ & 0 & 0.96 & 0.96 & 11 \\
\hline
\end{tabular}


Table 8

Delphi responses relating to specific voyage lengths.

\begin{tabular}{|c|c|c|c|c|c|}
\hline $\begin{array}{l}\text { 6. How will solely the driver shown affect specific average voyage lengths of } \\
\text { dry bulk hauls }(\mathrm{km}) \text { ? }\end{array}$ & Time & No reply & Mean R1 & Mean R2 & \% fall in s.d. \\
\hline $\begin{array}{l}\text { 6a. Due to: a Canadian N.W. Passage created by Arctic ice melt, average voyage } \\
\text { lengths N.E. Asia-W. Europe (km) will be: }\end{array}$ & $\eta$ & 3 & 0.93 & 0.94 & 9 \\
\hline $\begin{array}{l}\text { 6b. A Russian N.E. Passage arising from ice melt, average N.E. Asia-W. Europe } \\
\text { voyage lengths (km) will be: }\end{array}$ & $\eta$ & 3 & 0.93 & 0.95 & 11 \\
\hline $\begin{array}{l}\text { 6c. An enlarged Panama Canal, N.E. Asia-US East Coast voyage lengths (km) } \\
\text { averaged over all routes from } 2010 \text { to } 2030 \text { will be: }\end{array}$ & $\alpha$ & 0 & 0.93 & 0.93 & 8 \\
\hline $6 d . . .$. and from 2030 to $2050 \ldots$ & $\beta$ & 0 & 0.94 & 0.95 & 8 \\
\hline $\begin{array}{l}\text { 6e. Ship re-routing to avoid piracy caused by droughts and failed states, voyage } \\
\text { lengths }(\mathrm{km}) \text { N.E. Asia-W. Europe averaged over all routes will be: }\end{array}$ & $\eta$ & 3 & 1.09 & 1.08 & 5 \\
\hline
\end{tabular}

are consistent with the UK Committee on Climate Change (2011) estimates, but a Carbon Capture and Storage scenario (Mander et al., 2012) which envisaged that imports of biofuel pellets from Canada and olive cake from Spain would replace all coal from Russia, the US and Columbia was too radical for panelists in this survey. All three studies agreed that growing UK demand for biofuels would significantly reduce UK demand for coal imports, but the timing and extent of changes varied. In this survey, the estimates of $25 \%$ reduction in coal freight work arising from biofuels growth plus $9 \%$ additional reduction attributable to intolerance of fossil fuels are substantial but less radical than some estimates (Mander et al., 2012). Interestingly, an initial R1 mean estimate that increasing UK self-sufficiency in biofuels would significantly reduce biofuel import shipping demand before 2030 was moderated in R2, as were the perceptions of stronger impacts of dematerialization of the UK economy. It is conceivable that this panel which included relatively high proportions of early career and multinational shipping specialists might have been more optimistic or less well versed regarding the technological feasibility of large scale carbon capture and storage developments to enable more ongoing electricity generation using coal fired power stations than UK government energy specialists and advisers. However, this panel did agree with the UK Committee on Climate Change that port capacity was likely to suffice to 2050 .

\section{Conclusion}

Production and sourcing strategies will be influenced increasingly by sustainability considerations, raised awareness of climate change and the impacts of shipping decisions on atmospheric emissions. Over time the regulatory and social pressures on producers and dry bulk shippers to change will increase. Global dry bulk shipping demand is expected to double by 2050 , shifting increasingly towards imports of iron ore, coal and grain shipments to satiate rising consumer expectations in developing economies. While there is disagreement about precisely when and how dry bulk shipping demand will change, there is broad consensus that at least in developed economies, fossil fuel energy generation without effective carbon capture and storage will become unacceptable, shifting shipping demand from imports of coal to biofuels. Cost minimization motives will drive radical restructuring of sourcing strategies to embrace local and regional sourcing to minimize bunker costs, coupled with multi-sourcing to secure supplies. Infrastructural shifts including upgraded canals and Arctic passages offer shorter hauls, but any such shipping freight work reductions are partially offset by expected re-routing which lengthens hauls to avoid piracy threats and ECAs. Any impacts on shipping emissions of maritime regulations requiring more efficient ship designs, operating procedures and management plans are additional to these dry bulk market drivers.

Realistic forecasts of future ship flows for different types of ships underpin policy formulation and evaluation in maritime logistics, including strategies to deliver low carbon shipping. In the UK a likely spatial momentum of expected origin and destination ports servicing dry bulk shipping flows reflects geographically inert configurations of deep-water ports. However, even within one country, volatile domestic production strategies and consumption of coal and steel introduce uncertainty, which is amplified at the global scale

Table 9

Delphi responses relating to average UK haul lengths.

\begin{tabular}{|c|c|c|c|c|c|}
\hline 7. How will solely the driver shown affect the average lengths of UK dry bulk shipping hauls? & Time & No reply & Mean R1 & Mean R2 & $\%$ fall in s.d. \\
\hline $\begin{array}{l}\text { 7a. Rising bunker costs which favor sources closer to UK will cause average UK import hauls } \\
(\mathrm{km}) \text { to be: }\end{array}$ & $\eta$ & 4 & 1.00 & 0.95 & 29 \\
\hline $\begin{array}{l}\text { 7b. More ship re-routing to avoid piracy will cause average Australia-UK dry bulk hauls (km) } \\
\text { from } 2010 \text { to } 2030 \text { to be: }\end{array}$ & $\alpha$ & 3 & 0.95 & 1.05 & 3 \\
\hline 7c. ... and from 2030 to $2050 \ldots$ & $\beta$ & 3 & 1.07 & 1.03 & 13 \\
\hline $\begin{array}{l}\text { 7d. More ship re-routing to avoid ECA will cause average UK raw material bulker import } \\
\text { hauls (km) from } 2010 \text { to } 2030 \text { to be: }\end{array}$ & $\alpha$ & 5 & 1.04 & 1.04 & -16 \\
\hline 7e. ... and from 2030 to $2050 \ldots$ & $\beta$ & 5 & 1.04 & 1.02 & 5 \\
\hline
\end{tabular}


Table 10

Delphi responses relating to drivers of UK demand.

\begin{tabular}{|c|c|c|c|c|c|}
\hline 8. How will solely the driver shown affect specified components of UK dry bulk shipping demand? & Time & No reply & Mean R1 & Mean R2 & $\%$ fall in s.d. \\
\hline 8a. Growth in biofuels will cause UK demand for bulkers to import coal (tkm) from 2010 to 2030 to: & $\alpha$ & 17 & 0.79 & 0.88 & 29 \\
\hline 8b. .... and from 2030 to $2050 \ldots$ & $\beta$ & 2 & 0.92 & 0.87 & -24 \\
\hline $\begin{array}{l}\text { 8c. Increasing UK self-sufficiency in biofuel production will cause UK demand for bulkers (tkm) to } \\
\text { import biofuels from } 2010 \text { to } 2030 \text { to: }\end{array}$ & $\alpha$ & 4 & 0.86 & 0.99 & 27 \\
\hline $8 d . . .$. and from 2030 to $2050 \ldots$ & $\beta$ & 2 & 0.98 & 0.96 & -3 \\
\hline $\begin{array}{l}\text { 8e. Rising cost and requirements to capture carbon from coal fired power stations will cause UK } \\
\text { demand for bulkers to import coal (tkm) to: }\end{array}$ & $\eta$ & 4 & 0.97 & 0.96 & 5 \\
\hline $\begin{array}{l}\text { 8f. As UK society becomes less tolerant of using fossil fuels to produce energy, this will cause UK } \\
\text { demand for bulkers to import coal (tkm) to: }\end{array}$ & $\eta$ & 5 & 0.94 & 0.91 & 9 \\
\hline $\begin{array}{l}\text { 8g. A reducing role for manufacturing in the UK economy will cause UK demand for bulkers to } \\
\text { import raw materials (tkm) to: }\end{array}$ & $\eta$ & 5 & 0.88 & 0.97 & 3 \\
\hline 8h. The number of operational UK deep water dry bulk terminals will: & $\eta$ & 5 & 0.96 & 1.02 & 14 \\
\hline
\end{tabular}

as volatile cost, geopolitical and regulatory fluctuations continuously redefine optimal routing and sourcing policy, compounded by new and yet unknown resource and technological developments. Forty-year Delphi projections even from specialists with long-term career expectations were necessarily speculative and often conservative, but offer useful insights to supplement statistical forecasts. Because of this complexity, maritime flow forecasts are interlinked with macro-economic decisions, developments in marine technology, logistical and supply chain sourcing, mode choice and routing decisions, micro and macro-economic developments, regulatory changes, and operational strategies which also drive shipping policy. Future work might attempt to gather these interdependent strands into an integrated generic systems model capable of combining complex operating and regulatory decisions taken across and beyond the shipping sector, to enable scenario dependent testing of combinations of technologies and operational strategies.

\section{Acknowledgments}

The support of our research sponsors, the UK Engineering and Physical Sciences Research Council (EP/H019782/1) and industry (in particular Lloyds Register) is gratefully acknowledged.

\section{References}

Alizadeh, A.H., Nomikos, N., 2010. An overview of the dry bulk shipping industry, In: Grammenos, C.T. (Ed.), The Handbook of Maritime Economics and Business, 2nd ed.Lloyd's List, London.

Ariel, A., 1989. Delphi forecast of the dry bulk shipping industry in the year 2000. Marit. Policy Manag. 16 (4), 305-336.

Beenstock, M., Vergottis, A., 1993. Econometric Modelling of World Shipping. Chapman and Hall, London.

Bijwaard, G.E., Knapp, S., 2009. Analysis of ship cycles - the impact of economic cycles and ship inspections. Mar. Policy 33 (2), 350-360.

Bilgen, B., Ozkarahan, I., 2007. A mixed-integer linear programming model for bulk grain blending and shipping. Int. J. Prod. Econ. 107 (2), 555-571

Buhaug, Ø., Corbett, J.J., Endresen, Ø., Eyring, V., Faber, J., Hanayama, S., Lee, D.S., Lee, D., Lindstad, H., Mjelde, A., Pålsson, C., Wanquing, W., Winebrake, J.J., Yoshida, K., 2009. Second IMO Greenhouse Gas Study. International Maritime Organization, London.

Cetin, C.R., Cerit, G., 2010. Organisational effectiveness at seaports: a systems approach. Marit. Policy Manag. 37 (3), 195-219.

Chen, S., Frouws, K., Van de Voorde, E., 2010. Technical changes and impacts on economic performance of dry bulk vessels. Marit. Policy Manag. 37 (3), 305-327.
Committee on Climate Change, 2011. Review of UK Shipping Emissions. The Committee on Climate Change, London.

Czinkota, M.R., Ronkainen, I.A., 1997. International business and trade in the next decade: report from a Delphi study. J. Int. Bus. Stud. 28 (4), 827-844.

Department of Energy and Climate Change, 2011. The Carbon Plan: Delivering our Low Carbon Future. HM Government, London.

DfT, 2009. Maritime Statistics 2008. Department for Transport, London.

Dinwoodie, J., Chowdhury, N., Landamore, M., 2011. Low carbon shipping: dry bulk movements involving the UK. Logistics Research Network Annual Conference, University of Southampton, September 2011.

Dinwoodie, J., Tuck, S., Rigot-Müller, P., 2013. Maritime oil freight flows to 2050: Delphi perceptions of early career specialists. Energy Policy 63, 553-561.

Engelen, S., Dullaert, W., Vernimmen, B., 2007. Multi-agent adaptive systems in dry bulk shipping. Transp. Plan. Technol. 30 (4), 377-389.

Fowkes, T., Preston, J., 1991. Novel approaches to forecasting the demand for new local rail services. Transp. Res. A 25a (4), 209-218.

Gilbert, P., Bows, A., Starkey, R., 2010. Shipping and Climate Change: Scope for Unilateral Action. Tyndall Centre, University of Manchester, Manchester.

Glen, D.R., 2006. The modelling of dry bulk and tanker markets: a survey. Marit. Policy Manag. 33 (5), 431-445.

Gupta, U.G., Clarke, R.E., 1996. Theory and applications of the Delphi technique (1975-1994). Technol. Forecast. Soc. Chang. 53 (2), 185-211.

Hammer, J., 2009. Long-term oil tanker demand. Managing Risk, 2. Det Norske Veritas, Oslo (Accessed 14.02.11 http://www.dnv.com/industry/ maritime/publicationsanddownloads/publications/dnvtankerupdate/2009/ 2_2009/Longtermoiltankerdemand.asp).

Hasson, F., Keeney, S., 2011. Enhancing rigour in the Delphi technique research. Technol. Forecast. Soc. Chang. 78 (9), 1695-1704.

HM Treasury, 2006. Stern Review: The Economics of Climate Change. HM Treasury, London (http://webarchive.nationalarchives.gov.uk/+/http:// www.hm-treasury.gov.uk/stern_reviewreport.htm (accessed 13.01.11)).

International Maritime Organization, 2012. International Maritime Organization, London (http://www.imo.org. (accessed 20.01.12)).

Islam, D.M.Z., Dinwoodie, J., Roe, M., 2006. Promoting development through multimodal freight transport in Bangladesh. Transp. Rev. 26 (5), 571-591.

Kaluza, P., Kölzsch, A., Gastner, M.T., Blasius, B., 2010. The complex network of global cargo ship movements. J. R. Soc. Interface 7 (48), 1093-1103.

Kavussanos, M.G., Alizadeh, M.A.H., 2001. Seasonality patterns in dry bulk shipping spot and time charter freight rates. Transp. Res. E 37 (6), 443-467.

Korinek, J., Sourdin, P., 2009. Maritime transport costs and their impact on trade. OECD Paper (August. Accessed 10 Jan. 2011, http://www.etsg.org/ ETSG2009/papers/korinek.pdf).

Kuusi, O., Meyer, M., 2002. Technological generalizations and leitbilder - the anticipation of technological opportunities. Technol. Forecast. Soc. Chang. 69 (6), 625-639.

Lai, K.-h., Wong, W.Y.C., Cheng, T.C.E., 2012. Ecological modernisation of Chinese export manufacturing via green logistics management and its regional implications. Technol. Forecast. Soc. Chang. 79 (4), 766-770.

Landeta, J., 2006. Current validity of the Delphi method in social sciences. Technol. Forecast. Soc. Chang. 73 (5), 467-482.

Laulajainen, R., 2006a. A static theory of dry bulk freight rates by route. Marit. Policy Manag. 33 (5), 447-461.

Laulajainen, R., 2006b. Dry bulk shipping market inefficiency, the wide perspective. J. Transp. Geogr. 15 (3), 217-224.

Linstone, H.A., Turoff, M., 1975. Introduction. In: Linstone, H.A., Turoff, M. (Eds.), The Delphi Method Techniques and Applications. Addison-Wesley, Reading. 
Lloyd's Register, 2013. Global Marine Trends 2030. Lloyd's Register Strategic Research, London and Singapore (www.lr.org/gmt2030 (accessed 20.04. 2013)).

Lun, Y., Quaddus, M., 2009. An empirical model of the bulk shipping market. Int. J. Shipp. Transp. Logist. 1 (1), 37-54.

Lun, Y.H.V., Lai, T.C.K.-h., Cheng, D., 2013. An evaluation of green shipping networks to minimize external cost in the Pearl River Delta region. Technol. Forecast. Soc. Chang. 80 (2), 320-328.

Lynch, M.E., Imada, S.J., Bookbinder, J.H., 1994. The future of logistics in Canada: a Delphi-based forecast. Logist. Transp. Rev. 30 (1), 95-112.

Makukha, K., Grey, R., 2004. Logistics partnerships between shippers and logistics service providers: the relevance of strategy. Int. J. Logist. Res. Appl. 7 (4), 361-377.

Mander, S., Walsh, C., Gilbert, P., Traut, M., Bows, A., 2012. A Systems Perspective on Decarbonising the UK Energy System - The Impacts on Shipping $\mathrm{CO}_{2}$ Emissions, International Conference on Technologies, Operations, Logistics and Modelling for Low Carbon Shipping. The University of Newcastle, Newcastle, U.K.

Markmann, C., Darkow, I.-L., von der Gracht, H., 2013. A Delphi-based risk analysis - identifying and assessing future challenges for supply chain security in a multi-stakeholder environment. Technol. Forecast. Soc. Chang. 80 (9), 1815-1833.

Marlow, P., Gardner, B., 1980. Some thoughts on the dry bulk shipping sector. J. Ind. Econ. 29 (1), 71-84.

Nowack, M., Endrikat, J., Guenther, E., 2011. Review of Delphi-based scenario studies: quality and design considerations. Technol. Forecast. Soc. Chang. 78 (9), 1603-1615.

Osler, D., 2010. Tomorrow's World. Lloyds List, London (30 June).

Parsons, J., Dinwoodie, J., Roe, M., 2011. Northern opportunities: a strategic review of Canada's Arctic icebreaking services. Mar. Policy 35 (4), 549-556.

Pätäri, S., Puumalainen, K., Jantunen, A., Sandstrüm, J., 2011. The interface of the energy and forest sectors-potential players in the bioenergy business. Int. J. Prod. Econ. 131 (1), 322-332.

Piecyk, M.I., McKinnon, A.C., 2010. Forecasting the carbon footprint of road freight transport in 2020. Int. J. Prod. Econ. 128 (1), 31-42.

Scarsi, R., 2007. The bulk shipping business: market cycles and shipowners biases. Marit. Policy Manag. 34 (6), 577-590.

Shih, L.-H., 1997. Planning of fuel coal imports using a mixed integer programming method. Int. J. Prod. Econ. 51 (3), 243-249.

Smith, T.W.P., O'Keeffe, E., 2013. GloTraM User Guide. University College London.

Smith, T.W.P., Bucknall, R.W.G., Dinwoodie, J., Gibbs, D., Mangan, D.J., Turan, O., 2010. Low carbon shipping - a systems approach. Proceedings of RINA Ship Design and Operation for Environmental Sustainability, London, 11 March.

Smyth, R., Narayan, P.K., Shi, H., 2012. Inter-fuel substitution in the Chinese iron and steel sector. Int. J. Prod. Econ. 139 (2), 525-532.

Song, D.-W., Lee, E.-S., 2012. Coopetitive networks, knowledge acquisition and maritime logistics value. Int. J. Logist. Res. Appl. 15 (1), 15-35.

Steinert, M., 2009. A dissensus based online Delphi approach: an explorative research tool. Technol. Forecast. Soc. Chang. 76 (3), 291-300.

Stopford, M., 2009. Maritime Economics, 3rd edition. Routledge, London.

Stott, P.W., Wright, P.N.H., 2012. The Panama Canal expansion: business as usual or game changer for ship design? Port Technol. Int. 53 (1), 27-28.

Tamvakis, N.T., Thanopoulou, H.A., 2000. Does quality pay? The case of the dry bulk market. Transp. Res. E 36 (4), 297-307.
Tapio, P., 2002. Disaggregative policy Delphi: using cluster analysis as a tool for systematic scenario formation. Technol. Forecast. Soc. Chang. 70 (1), 83-101.

Turoff, M., 1970. The design of a policy Delphi. Technol. Forecast. Soc. Chang. 2 (2), 149-171.

Verny, J., Grigentin, C., 2009. Container shipping on the Northern Sea Route. Int. J. Prod. Econ. 122 (1), 107-117.

von der Gracht, H.A., 2012. Consensus measurement in Delphi studies: review and implications for future quality assurance. Technol. Forecast. Soc. Chang. 79 (8), 1525-1536.

von der Gracht, H.A., Darkow, I.-L., 2010. Scenarios for the logistics services industry: a Delphi-based analysis for 2025. Int. J. Prod. Econ. 127 (1), 46-59.

W.C.I., 2005. The Coal Resource: A Comprehensive Overview of Coal. World Coal Institute, London (Accessed (20.01.12) www.worldcoal.org).

W.C.I., 2009. Coal Facts 2009 Edition with 2008 Data. World Coal Institute (Accessed 10 June 2011, www.worldcoal.org).

Wang, C., Corbett, J.J., 2007. The costs and benefits of reducing $\mathrm{SO}_{2}$ emissions from ships in the US West Coastal waters. Transp. Res. D 12 (8), 577-588.

John Dinwoodie is the leader of the International Shipping and Logistics Group, and a Professor in the Graduate School of Management of Plymouth University. He was Principal Investigator at Plymouth University in the five university consortium EPSRC-funded Low Carbon Shipping: A Systems Approach project. He is Lead Academic in the UK ESRC award winning best application of social science in a Knowledge Transfer Partnership, 2012 with Falmouth Harbour Commissioners. He has published a book, numerous book chapters, and over thirty journal articles and delivered over one hundred conference papers in the fields of international shipping, logistics and supply chain management.

Melanie Landamore, School of Marine Science and Technology at Newcastle University (MEng, MBA). Melanie is the economics WP joint leader for the EPSRC-funded Low Carbon Shipping: A Systems Approach project, and Policy \& Strategy WP leader for the Interreg IVB project Clean North Sea Shipping. Her experience primarily involves research into sustainable shipping, through life environmental, economic and social accounting of ships, innovative concepts for European short sea shipping, and impacts of human factors on ship design and operation. She has also undertaken research into the life-cycle environmental and economic cost of leisure craft, and the establishment of a risk-based design methodology for environmental safety.

Patrick Rigot-Müller is a guest researcher at The Logistics Institute, Hull University Business School (HUBS). He has worked for the 'Low Carbon Shipping' consortium as a research associate, at HUBS and at Newcastle University (School of Marine Science and Technology). His research areas cover supply chain management and sustainable development. He has extensive industry knowledge, with more than 10 years of consulting experience. He is an engineer from the Federal University of Rio de Janeiro, has a master in scientific management from Université Paris-Dauphine and has a doctorate in management sciences from Ecole des Mines de Paris (Mines Paristech). 